\author{
Constitutions are the Answer! \\ Hannah Arendt and the Egyptian Revolution ${ }^{1}$ \\ Anthony F. Lang, Jr \\ School of International Relations \\ University of St Andrews
}

\title{
Introduction
}

On 25 January 2011, a large scale protest broke out in Tahrir Square in the centre of Cairo. Recent events in Tunisia, inspired by the suicide of a young fruit seller in response to police brutality, helped spur the revolutionaries. After only a few weeks, on 11 February 2011, the long time president Hosni Mubarak resigned, and a military government took power.

While Tunisia's political system has settled into a more stable order, Egypt has been through a tumultuous period since the fall of Mubarak. If the goal of the revolution was to create a democratic system in which human rights enjoy strong protections, this has not been achieved. At the time of this writing, the current president, Abdel-Fattah al Sisi has undertaken a large-scale crackdown on freedom of the press. A highly respected Egyptian television journalist was arrested on 4 March 2018 for suggesting that police are underpaid. ${ }^{2}$ After a BBC report on torture and disappearances in February 2018, the Egyptian authorities intensified their crackdown on foreign reporting and international broadcasters. ${ }^{3}$ Prior to the

\footnotetext{
${ }^{1}$ Parts of this chapter are drawn from some of my previous publications. These include "Arendt and the Question of Revolution" in Patrick Hayden, ed., Hannah Arendt: Key Concepts (London: Routledge, 2014): 167-184; "From Revolutions to Constitutions: The Case of Egypt" International Affairs 89, 2 (March 2013): 345-364; and "Violence and International Political Theory" in Chris Brown and Robyn Eckersley, eds., The Oxford Handbook of International Political Theory (Oxford: Oxford University Press, 2018): 195-208.

${ }^{2}$ http://abcnews.go.com/International/wireStory/egypt-detains-pro-government-tv-host-police-segment53498339.

${ }^{3}$ Declan Walsh, “As Election Nears, Egypt Finds a New Target: Foreign News Media” The New York Times, 28 February 2018, available at: https://www.nytimes.com/2018/02/28/world/middleeast/egypt-elections-newsmedia.html.
} 
current election period, Human Rights Watch issued a report claiming that torture is now widespread again in Egypt, returning it to the worst excesses under the rule of Mubarak. ${ }^{4}$

Does this state of affairs mean that the revolutionary hopes of Tahrir Square are lost? How do we explain the failure of the revolution in Egypt? In this chapter, I draw on the insights of Hannah Arendt to understand this revolutionary experience. I am not the first to use Arendt's work to understand the revolutions in the Arab world..$^{5}$ And, to truly understand the rise and fall of the revolutionary spirit in Egypt would require a much more sustained analysis of the conditions within the country, its history, and the wider Arab and international context. Rather than such an extensive analysis, this chapter will seek instead to use Arendt's insights on revolution and constitutions as a means to illuminate certain elements of recent Egyptian history.

The argument of the chapter is that Egypt fell victim to the problem of modern revolutions which Arendt highlighted in her book On Revolution. Rather than seeking to create greater public freedom, Arendt argues that revolutions are quickly captured by an emotive and ultimately destructive search for the 'constituent power' of the people. In so doing, revolutions 'devour their children' as they did in the French Revolution's turn to the Terror because they idealize the morality of the people, ideals which can never be found in political life. In her comparison of the French and American revolutions, Arendt argued that the American revolutionaries did not fall victim to this dilemma as they drew on historical precedent and legal tradition, leading to the creation of a system that made space for power. Rather than search for a true people, which leads to the creation of enemies and a strong

\footnotetext{
4 "We Do Unreasonable Things Here: Torture and National Security in al-Sisi's Egypt" Human Rights Watch Report, 5 September 2017, available at: https://www.hrw.org/report/2017/09/05/we-do-unreasonable-thingshere/torture-and-national-security-al-sisis-egypt.

${ }^{5}$ Antoni Abat I Ninet and Mark Tushnet, The Arab Spring: An Essay on Revolution and Constitutionalism (Cheltenham: Edward Elgar Publishers, 2015) and Jens Hanssen, "Translating Revolution: Hannah Arendt in Arab Political Culture", November 2013 HannahArent.net, available online at: http://www.hannaharendt.net/index.php/han/article/view/301.
} 
moralism, the American founders avoided this through their deliberately designed constitutional order.

The political writings of the Egyptian novelist and liberal commentator, Alaa al Aswany reflects the problem that Arendt identified. His book of newspaper columns, written over the period from 2011 to 2014, is entitled Democracy is the Answer, the phrase with which he ends each of his articles. As he writes in an article from 25 June 2012, immediately following the election of the Muslim Brotherhood leader, Mohammed Morsi, to the presidency:

How many times have you said, or heard someone say, that Egyptians are not ready for democracy? ... I have heard people state these opinions scores of times inside and outside Egypt, and I always explain to them that the history of modern Egypt shows that the Egyptian people have always behaved with real political awareness. I continue by telling them that they are talking about the Egyptian people as if they were a hypothetical concept or expression, rather than real people. The Egyptian nation is made up millions of people who may differ in their social background or education, but at a certain moment a common national feeling and outlook makes them take a unified and often correct stance. It is the Egyptian nation that made all the Egyptian revolutions. ${ }^{6}$

Al Aswany's words here mirror those of the French Revolutionaries and the thinking of Rousseau, who sought to find the true people who could embody the moral righteousness of their cause. Admittedly, Al Aswany has fought hard to protect the Egyptian revolutionary spirit, but, as I hope to show, it is this attitude and ideal which distorts a revolution and turns it away from the primary goal of achieving public freedom.

The chapter proceeds as follows: The next section provides an overview of the Egyptian revolution, with a focus on some key developments relating to constitutional issues. The second section reviews Arendt's ideas about constituent power, connecting this idea back to the dynamics of the Egyptian context. The third section turns to Arendt's ideas about

\footnotetext{
${ }^{6}$ Alaa al Aswany, Democracy is the Answer: Egypt's Years of Revolution, translated by Russel Harris, Aran Byrne, and Paul Naylor (London: Gingko Library, 2014): 256.
} 
constitutions and institution building. I conclude with some reflections on what Arendt's ideas tell us about the future of the Egyptian revolution and the constitutions that have resulted therefrom.

\section{The Egyptian Revolution}

Following the first days of the protests in January 2011, protests rapidly increased, especially in Cairo. ${ }^{7}$ The military deployed, replacing the police as the primary guarantors of security in Cairo. According to most reports, they did not use force against the protestors, perhaps defying the orders of the regime. Soon thereafter, President Hosni Mubarak spoke to the nation and blamed the protests on the Muslim Brotherhood and indicated he would not run for another term in office. The protests were not mollified by Mubarak's addresses and only increased in intensity. A few days later, on 11 February, the Vice President announced that Mubarak had resigned and that the Supreme Council of the Armed Forces (SCAF) would take over.

If a revolution was simply about the removal of those in power, then this would be the end of the story. However, as Arendt reminds us, a revolution differs from a rebellion in its devotion to the creation of public freedom, which it undertakes through the creation of a new constitutional order. And the political dynamics that followed often focused on constitutions and efforts to create a constituent assembly that reflected the people. One way to understand the dynamics of this process is through the idea of constituent power. Constituent power, as defined by Martin Loughlin, is the "power of the people to make and remake the institutional arrangements through which they are governed". ${ }^{8}$ As will become evident in what follows,

\footnotetext{
${ }^{7}$ This historical summary is based on a number of sources. For one example, which contextualizes the revolution through an analysis of Egypt since the time of Nasser, see Steve Cook, The Struggle for Egypt: From Nasser to Tahrir Square (Oxford: Oxford University Press, 2012), especially pages 272-307.

${ }^{8}$ Martin Loughlin, “The Concept of Constituent Power," European Journal of Political Theory (2014) 13, 2: 219.
} 
much of the debate in Egypt revolved around how to transfer this constituent power into constitutional form, a process that one collection calls the "paradox of constitutionalism". 9

The first steps in turning the revolution into a new constitution were timid. Rather than an entirely new constitution, the SCAF proposed a series of amendments to the existing constitution (which dated from 1971). The group that created the constitutional amendments was headed by Tarek al-Bishry, a public intellectual in Egypt who had been critical of the Mubarak regime prior to his appointment. In an article in the Guardian, he argued explicitly that the legitimacy of the SCAF was "revolutionary" rather than constitutional. ${ }^{10}$ This suggested that he might see his role as one of capturing the constituent power of the revolution and turning into a new legitimate constitutional form.

Tensions emerged surrounding the creation of the assembly that would draft the constitution. When the transition was still in its early stages, some warned that this procedure would be drawn out and should be left to experts. ${ }^{11}$ The problem of forming a constitutional assembly came to dominate the news in Egypt during the spring and summer of 2011. One controversy that emerged was whether elections to the parliament should be held before or after the convening of a constitutional assembly. Some argued that a constitution needed to come first, so that the elected parliament would have something by which to govern. Others argued that only a representative parliament would be able to create a constitutional assembly, as it would be the most representative. ${ }^{12}$

When parliamentary elections were held in autumn 2011, the Muslim Brotherhood's Freedom and Justice Party won the largest number of seats; they then combined with the

\footnotetext{
${ }^{9}$ Martin Loughlin and Neil Walker, eds. The Paradox of Constitutionalism: Constituent Power and Constitutional Form (Oxford: Oxford University Press, 2007).

10 Tarek El-Bhsiry, "Egypt's New Legitimacy” The Guardian, 21 March 2011, available at: http://www.guardian.co.uk/commentisfree/2011/mar/21/egypt-referendum-constitution-legitimacy-change.

${ }^{11}$ Nathan Brown, "Egypt's Constitutional Ghosts” Foreign Affairs (February 2011), reprinted at Carnegie Endowment for International Peace, http://carnegieendowment.org/2011/02/15/egypt-s-constitutionalghosts/930.

${ }^{12}$ Al-Aswany, Democracy is the Answer, 67.
} 
more extreme Islamic political party, Al Nour, to create a majority in parliament. ${ }^{13}$ This parliament took on the responsibility of creating the constitutional assembly to draft a new constitution and, as a result, was dominated by the Muslim Brotherhood and the other Islamist parties. Soon after its formation, however, a number of members boycotted it, claiming it was unrepresentative. ${ }^{14}$ This debate struck at the heart of the effort to turn constituent power into constitutional form, particularly as it raised the question of how to measure that constituent power; should it reflect the parliament, where a majority were from Islamist parties or should it represent groups in society? Those objecting included Egyptian Christians, the liberal Wafd Party and even representatives from the Islamic University, Al Azhar. These groups brought a challenge to an administrative court, which ruled that the assembly was not legal. The commission met twice and began structuring its process around the creation of five committees.

Throughout the spring and summer of 2012, various efforts were made to reform the constitutional assembly. In June 2012, the SCAF demanded that the political parties and parliament produce a constitutional assembly, or it threatened to create one on its own. On 12 June 2012, the parliament announced the names of the 100 members of a new constitutional assembly, along with rules to guide their deliberations. ${ }^{15}$ The assembly retained a majority of Islamist members, but it had more diversity than the previous assembly.

In the midst of this process, a presidential election was held which brought to power a long-time member of the Muslim Brotherhood, Mohammed Morsi. Facing challenges from the judiciary over the legitimacy of both the parliament and the constitutional assembly, on

\footnotetext{
${ }^{13}$ The Muslim Brotherhood is not officially a political party, but a political movement. The Freedom and Justice Party was created by the MB, although the links between them are somewhat unclear. The more extreme al Nour party was created as a vehicle for more conservative Islamicist parties. For an overview of the different parties prior to the elections, see the BBC webste: http://www.bbc.co.uk/news/world-middle-east-15899548. ${ }^{14}$ Gamal Essam El-Din, “A Stilborn Assembly” in Al Ahram Weekly, 5-11 April, 2012, available from http://weekly.ahram.org.eg/2012/1092/eg1.htm.

15 “Official: The 100 Members of Egypt's Revamped Constituent Assembly" AlAhram Online, 12 June 2012, available at: http://english.ahram.org.eg/NewsContent/1/64/44696/Egypt/Politics-/Official-The--members-ofEgypts-revamped-Constitue.aspx.
} 
22 November 2012, Morsi declared that no presidential laws and decrees could be challenged until the new constitution was finalized. Morsi's move sought to protect the two institutions which were dominated by the Muslim Brotherhood, the constitutional assembly and the parliament, but also the two institutions which seemed to reflect the reality of the constituent power. The judiciary was seen by Morsi and others to be a holdover from the Mubarak era, though recent history suggests otherwise. The judiciary, while certainly defenders of the existing legal system in many ways, had been surprisingly active in protesting against the Mubarak regime. From 2005 through 2007, reformist judges had actively resisted efforts by the executive branch to limit its powers, both in terms of its internal governance as a branch of government and in its role as election monitors. ${ }^{16}$ This resistance culminated in their decision to join the protests in February 2011.

Though he claimed to be protecting the will of the people as opposed to unelected judges, Morsi's declaration infuriated the opposition and the international community. It did, however, force the constitutional commission to finalize its work and produce a draft constitution on 29 November 2012. On 25 December 2012, it was announced that the new constitution had been approved in the referendum, with approximately $63 \%$ voting in favour, though only $33 \%$ of the population voted. ${ }^{17}$ This raised a number of doubts about the representative nature of the constitution, i.e., did it really capture the constituent power of the people?

The draft constitution built upon but also altered the 1971 constitution. Reflecting the wishes of the Islamist party members of the assembly, the text retained the language of the previous constitution which stipulates that "Principles of Islamic Sharia are the principal

\footnotetext{
${ }^{16}$ For an overview of their activism during this period, along with a wider discussion of the role of the judiciary in the Mubarak era, see Nathalie Bernard-Muagiron, ed., Judges and Political Reform in Egypt (Cairo: The American University in Cairo Press, 2008).

${ }^{17}$ Bernard Rougler and Stéphane Lacroix, "Introduction", eds., Egypt's Revolutions: Politics, Religion and Social Movements, translated by Cynthia Schoch with the participation of John Angell (London: Palgrave Macmillan, 2016): 9.
} 
source of legislation (Article 2). Yet, it narrowed the scope of how that principle can be interpreted in Article 219 when it stated that "The Principles of Islamic Sharia include general evidence, foundational rules, rules of jurisprudence, and credible sources accepted in Sunni doctrines and by the larger community." This article results in a Sunni Islamic interpretation of the text, one which might disenfranchise Shia Muslims who make up a sizable minority in Egypt. The new constitution also stated that the president was now limited to two terms of four years each, a crucial change from the long standing presidential dominance in Egypt (Article 133). The legislature was to be composed of a House of Representatives and a Shura Council, with more power given to the former than the latter. The judiciary was altered in important ways, weakening it by lowering the numbers of the Supreme Constitutional Court and defining more carefully its ability to become involved in electoral matters. This constitution, however, did not last long, nor did the presidency of Morsi. In August 2012, Morsi appointed General al-Sisi as the new head of SCAF, an individual with whom he had worked during the transition period and whom he believed he could trust.

In April 2013, an opposition group calling itself Tamarod emerged. Led by a young activist named Mahmoud Badr it aimed to collect 15 million signatures by 30 June 2013, the one-year anniversary of Morsi's election to power. It organized large scale protest movements in Cairo. The Morsi government refused to recognize its constituent power, claiming its leadership had been infiltrated by the intelligence community and military. Once the protests erupted, the SCAF, led by General al-Sisi, demanded a resolution to the crisis by 3 July 2013 or it would step in. When neither side budged, the military did just this, leading to the collapse of the Morsi government.

An interim president was named, but power returned to the SCAF. One of its first acts was to dissolve the 2012 constitution and create a new constitutional assembly. A group of 10 
legal experts began the process by amending the 2012 constitution, which then was sent to a constitutional assembly of 50 people. The composition of this assembly was just as controversial as the 2012 committee. Of the 50 members, only 6 were drawn from political parties and of these, only two represented Islamic groups. The remaining members were drawn from a diverse range of social groups, including artists, literary figures, labour members, activists, and other religious groups. ${ }^{18}$ In addition, the military was represented, though from the reports of some members, the power of the military was debated, and efforts were made to limit its role in the new political order. ${ }^{19}$ Other groups, such as farmers and workers, sought to ensure that their interests were protected in the process. ${ }^{20}$ The constitution which emerged from this assembly was approved in a referendum on 15 January 2014, with a $98 \%$ approval rate, though turnout was only at $38 \%$.

The constitution made some important changes to the political system. For one thing, it eliminated the Shura Council, the upper house of parliament, which acted in a capacity closer to the House of Lords in the UK system than to the Senate in the US system. It allowed the military to retain much of its power within the system, though it retained the limit to two terms for the president of the 2012 constitution. It also took out the controversial Sunni interpretative clauses of the 2012 constitution, though retained the language that "Sharia is the source of legislation" which had first appeared in the 1971 constitution.

Zaid al-Ali, a renowned constitution expert, argued that the 2014 constitution failed to guarantee a number of crucial rights, including freedom of speech and freedom of association. He suggests that more detail is necessary about how such rights would be enforced. In addition, he argued that the 'limitation clause', or the clause that provides

\footnotetext{
${ }^{18}$ The full list of members with affiliations can be found here: http://english.ahram.org.eg/News/80519.aspx.

${ }^{19}$ Ashfar Khalil, "Egypt's Committee of 50 Rewrites the Constitution - Again” Al Jazeera America 11 November 2013, available at: http://america.aljazeera.com/articles/2013/11/11/egyptconstitutioncommitteeof50.html.

${ }^{20}$ Fattouh al Chazli, "Egypt's Constitutional Drafting: A Comparative Review” The Legal Agenda, 31 December 2013, available at: http://www.legal-agenda.com/en/article.php?id=2958.
} 
guidance on the limits that can be imposed on rights, is far too general and needs more specificity. Al-Ali also detailed changes to the government's structure, criticizing it for failing to decentralize the system and, interestingly, for giving more independence to the judiciary. According to al-Ali the judiciary is so corrupt that giving it more power would not solve this problem. ${ }^{21}$

The final point to note is that General al Sisi became President al Sisi in June 2014. In April 2018, he was re-elected president in a widely disputed vote, one that most observers agreed was rigged. As noted in the introduction, the course of events since 2014 in Egypt has not been promising in terms of creating a climate of public freedom. The power of the executive has increased and he has limited the rights to free speech across a range of issues. There are many reasons for the decline of freedom in Egypt. In the next section, however, I turn to Hannah Arendt's analysis of revolutions to see if she can provide any insights into the Egyptian experience.

\section{Arendt on Revolution, Constituent Power, and Public Freedom}

The uprising that broke out in Egypt was about freedom. To act together to create a new political order reflects Arendt's core philosophical insight on freedom: 'The raison d'etre of politics is freedom, and its field of experience is action'. ${ }^{22}$ The proliferation of terms to describe the events in Egypt and the wider Arab world reveal not only uncertainty about these events but about the very nature of revolution. Arab Spring, Arab Uprisings, and Arab Revolutions have all been used in the literature around these events. For some analysts of the events in the Arab world, particularly those writing from the West, it is the failure to establish a liberal democratic order which prevents these events being called revolutions; Zaid al-Ali's

\footnotetext{
${ }^{21}$ Zaid al Ali, "Egypt's Third Constitution in Three Years: A Critical Analysis" in Rougier and Lacroix, eds., Egypt's Revolutions: 123-138.

${ }^{22}$ Hannah Arendt, "What is Freedom?" in Between Past and Future: Eight Exercises in Political Thought (New York: Penguin, 1961): 146.
} 
critical reading of the 2014 constitution perhaps best represents this ideal and, to a lesser extent, Alaa al Aswany's columns. Arendt's insights help us to see these events as revolutions even if they have not established the outcomes that some would like to see. ${ }^{23}$

Ninet and Tushnet ask whether or not the revolutionary politics of the Arab Spring created a new space for freedom. Here, I would argue, they do not fully capture Arendt's understanding. They remind us that Arendt argued a revolution needs to create something new, but "truly new beginnings are no longer possible, only new beginnings for specific nations." They suggest that Arendt's criterion here is perhaps too rigid. Rather "A nation's people need not transform itself from one thing to another, it needs only to be liberated from oppression." 24 Arendt does indeed argue for natality as central to not just revolutions but to all political action. More accurately, she argues that for a revolution to succeed it must do more than simply seek to pull a community out of oppression or vent anger at oppressors, for this is what doomed the French revolution to failure. Instead, a revolution must seek to create a space for public freedom, a space in which individuals can then continue to create and recreate politics anew. The newness is not necessarily a radically new political ideology, only the establishment of new institutional forms that allows politics to flourish.

Arendt redefines revolution, starting with Machiavelli as its "spiritual founder". ${ }^{25}$ But she points out that Machiavelli was medieval enough that he still understood the word revolution as rebellion against the ruler. This meant that Machiavelli did not explicitly link revolution to the idea of freedom, that which essentially constitutes its meaning into the 16th and 17 th centuries. The meaning begins to change when a revolution is understood as the

\footnotetext{
${ }^{23}$ Arendt's reflections on violence and politics have been employed by two theorists who use Arendt to interpret the revolution. I do not look to this debate here, but there is much to be learned from their reflections on violence and whether or not this is important for defining the Arab Spring as a true revolution; see Antoni Abat I Ninet and Mark Tushnet, The Arab Spring: An Essay on Revolution and Constitution (Cheltenham: Edward Elgar, 2015): 4-5.

24 Ibid, 5.

${ }^{25}$ Hannah Arendt, On Revolution (New York: Penguin Books, 1963) 37.
} 
replacement of an entire political order rather than a ruler. Moreover, as Arendt points out, it changes by becoming linked to history in a new way. The modern meaning of the term, as Arendt explains, finds its origins in Copernicus' idea of the revolution of the planets. ${ }^{26}$ This connected with emerging trends in natural law, particularly those accounts that looked to the natural world for insight into the human condition. The confluence of newly secularized natural law and the civil war in Britain shaped the meaning of revolution. As Arendt explains, revolution was understood in this 17 th century context as a 'return' or the 'revolution' of a cyclical pattern that saw uprising and then a return to the monarchy, as in the Glorious Revolution of 1688.

As Arendt highlights, the inevitability of the naturalist account underwent a subtle shift in the 18th century, particularly in the context of the French Revolution. Its advocates no longer saw revolution as part of the natural order of things, but as an inevitable historical development; as she puts it, revolution was now understood as "the lawfulness of a rotating, cyclical movement to its irresistibility" ${ }^{27}$ This new meaning then intersects with historicist thinking in the 19th century, beginning with Hegel and continued by Marx, hence informing the social and communist idea of revolution. Their accounts found revolution to be part of a wider and longer historical process that left little room for the agency and natality of politics that Arendt develops across her works. Arendt argues the Hegelian and Marxian reading of the French Revolution is what shapes our understanding of the term, especially its valences of the inevitable and irresistible understood through the metaphors of 'currents', 'streams' and 'rivers'. Human agency is lost and all we can do is sit as spectators watching the flow of history: "What the men of the Russian Revolution had learned from the French Revolution and this learning constituted almost their entire preparation - was history and not action". ${ }^{28}$ In

\footnotetext{
${ }^{26}$ Ibid, 42.

${ }^{27}$ Ibid, 48-49.

${ }^{28}$ Ibid, 58.
} 
linking revolution first to the natural philosophy of the 17 th century and then the historicism of the late 18th and early 19th century, Arendt suggests that the idea of revolution cannot escape determinism, something that is, in fact, antithetical to the type of political agency that was at the core of her ideas.

Here again Arendt's ideas illuminate something about Egypt's revolution. Zaid al Ali argues that if Egypt's revolution is to truly create a liberal constitution, it must move away from the staid and traditional ideas promoted by the conservative forces in society. Instead, the drafting of the constitution should rely on "progressives" who can draft a constitution and then send it back to a wider representative body for approval. ${ }^{29}$ Recall as well that al Ali argued against increasing the power of the judiciary until it was completely reformed. These views reflect the thinking of the French and Bolshevik heritage about which Arendt wrote. But it raises the question of whether or not ignoring the social and legal traditions of a society will truly produce a workable constitution. One of the reasons for the success of the American constitution is that it adopted the existing common law tradition and even older natural law ideas. In creating new institutions, according to Arendt, the American founders did not disband their history. They built upon it in order to recreate the public freedom that is so essential to the success of a revolution.

The problem of revolution is further compounded by the introduction of the 'social question', which frames her discussion in Chapter 2 of On Revolution. The social was introduced as a problem for political life in The Human Condition, where Arendt develops a critique of how the private realm of the oikos (household) was mistakenly introduced into the public sphere of the polis (polity) ${ }^{30}$ For Arendt, the conflation of these realms undermines the political, for it reduces political agency to the mundane realm of feeding, clothing and

\footnotetext{
${ }^{29}$ Al Ali, "Egypt's Third Constitution in Three Years", p. 136.

${ }^{30}$ Hannah Arendt, The Human Condition (Chicago: University of Chicago Press, 1958); See also, Philip Walsh, "On the Social" in Patrick Hayden, ed., Hannah Arendt: Key Concepts (London: Routledge, 2014): 124-137.
} 
housing. The social appears in On Revolution as that which overwhelmed the French Revolution. Rather than a sphere of political life in which they could establish and constitute a new polity, as took place in the American Revolution, the French were forced to confront poverty which resulted in their revolutionary trajectory collapsing into violence.

At least, this is the dominant reading of Chapter 2 of On Revolution, and it connects well with Arendt's overriding concerns to privilege the political and political action. Instead of this reading, or perhaps in addition to it (for it is not completely false), I propose here an alternative; that her critique of the social in this section of the book is really a critique of the idea of constituent power as a way to understand how a revolution turns into a constitution or institutional structure. The point Arendt is making here is not to disparage the concern with feeding and clothing ourselves, or a critique of revolutions that arise from and seek to alleviate the problem of poverty. Rather she is critiquing the idea that a unified body politic brings about a revolution and can be easily transformed into a democratic political order, an idea that underlies the French revolution as a result of the influence of Rousseau and Abbe de Sieyes.

She begins Chapter 2 with a critique of Marx, one that parallels her critical engagement with his work in The Human Condition. But she moves from Marx to a more sustained critique of Rousseau and one aspect of Rousseau's work that she found particularly troubling - compassion. Compassion, etymologically, means 'suffering with' creating a unity with the other. Rousseau allowed compassion to come through to the political realm in the guise of the general will. But, as Arendt notes, a people is best unified in opposition to a foreign enemy, a fact that Rousseau transformed in his account:

Thus [Rousseau's] problem was where to detect a common enemy outside the range of foreign affairs, and his solution was that such an enemy existed within the breast of each citizen, namely, in his particular will and interest; the point of the matter was that this hidden, particular enemy could rise to the rank of a common enemy - unifying the nation from within - if one only added up all particular wills and interests... To partake in the body politic of 
the nation, each national must rise and remain in constant rebellion against himself. ${ }^{31}$

This internal conflict in the breast of each citizen had to be overcome by the general will in forcing the individual to be compassionate and selfless. Any appeal to interest or prudence in the creation of new institutions was negative, something that needed to be overcome so that the individual could lose him or herself in the general will, a will that emerged from the revolutionary moment. Constituent power, then, is defined by its selfless, compassionate nature, which would enable the creation of institutions to better the poor and deprived in society.

Rousseau's ideas about the general will connected with a belief in absolute goodness in human institutions. For if the desires that trouble the individual citizen could be eradicated by devotion to the good of the whole, this could result in a political life that was infused with good. But Arendt argues that this idealist conception of the political will result in its failure. Political institutions, once shorn of compassion, goodness and idealism, will be able to function as a means by which political agency can have a chance to flourish: "The tragedy is that the law is made for men, and neither for angels nor for devils. Laws and all 'lasting institutions' break down not only under the onslaught of elemental evil but under the impact of absolute innocence as well." 32

Arendt argues that what the American founders understood that the French did not is precisely this point - political institutions cannot work if they are intended to reflect a constituent power designed to create perfection. In Chapter 3, Arendt explores the nature of public freedom at that the American founders proposed in the framing of the Declaration of Independence and the Constitution. She highlights the idea of public 'happiness' arguing that happiness was not to be found in pleasures of the home but in public deliberation, in the

\footnotetext{
${ }^{31}$ Arendt, On Revolution, pp. 78-79.

${ }^{32}$ Arendt, On Revolution, p. 84.
} 
actions of citizens engaged in governing themselves. This pursuit of public happiness was only made possible because the American founders did not need to concern themselves with the drudgery of daily life, the life of the 'social' that so preoccupied the French revolutionary founders. These chapters have become the ammunition for those who want to claim Arendt as a champion of American exceptionalism. Indeed, there are passages of hagiography in the text, where she sees in figures such as John Adams and Thomas Jefferson paragons of what she understands as political agents. But to read Arendt in this triumphalist vein is a mistake; she notes, for instance, that American "slavery carries an obscurity even blacker than the obscurity of poverty"33 (though she does not seem to recognize the irony of her adjective in this sentence!).

How does this help us interpret the Egyptian context? Finding constituent power played a crucial role in the revolution. From the beginning, with the attempt to capture the revolutionary spirit in the March 2011 amendments to the ongoing debates about the composition of the different constituent assemblies, there has been a struggle to identify the true constituent power of the people. The composition of the constituent assemblies in 2012 and 2013 demonstrate the two different ideas underlying constituent power. On the one hand, the Muslim Brother dominated 2012 constitutional assembly represents what we might call a democratic conception of constituent power; that is, by relying on the vote of the people and the majority party in the parliament, it reflects the largest group. On the other hand, the 2013 constitutional assembly represents something closer to a pluralist conception of constituent power, one in which the component parts of the polity are reflected. Moreover, the 2013 assembly was working from a draft proposed to them by a group of 10 legal experts, hence bringing the legal traditions of Egypt's polity to bear on the process.

\footnotetext{
${ }^{33}$ Arendt, On Revolution, p. 71.
} 
I would argue that a republican conception of constituent power better reflects Arendt's ideas about political life. Of course, she was largely dismissive of the very concept of constituent power, as she read it primarily through the lens of the French Revolution and its failures. And, it is certainly the case that the 2013 constitutional assembly did not produce a constitution which has created greater "public freedom" if measured by the non-existence of a flourishing liberal democratic order in Egypt today. So while the constituent assembly of 2013 might better reflect Arendt's ideas of plurality than does the 2012 constituent assembly, what explains the failure of the constitution that emerged in 2014 from making any real change in Egyptian politics? To answer this question, let me turn to the final few chapters of On Revolution.

\section{Constituting a Revolution}

In the final chapters of On Revolution, Arendt examines the link between revolutions and constitutions, a link which is often overlooked by those who wish to find in this work a simple comparison of the French and American revolutions. She turns to Thomas Paine, the most radical of the American founders, to highlight what made these revolutionary moments so different and important: "A constitution is not the act of a government but of a people constituting a government." ${ }^{34}$ But what differentiated the American and French revolutions can be seen in the influence of Montesquieu on the Americans, for it was Montesquieu's ideas that enabled the Americans to combine freedom and power by recognizing the need to limit the institutions of government. Rather than rely on law alone to check power, Montesquieu understood that "Power can only be stopped and still be kept intact by power". ${ }^{35}$ Importantly, Montesquieu and the American founders were not only interested in limiting

\footnotetext{
${ }^{34}$ Arendt, On Revolution, p. 145.

${ }^{35}$ Arendt, On Revolution, p. 151.
} 
power, a point misunderstood by libertarians and free market interpreters of the American experience. Indeed, it is the way that power enables political action that so interested Arendt.

Arendt goes on to explore the relationship of power to law. She argues that the power, the constituent power of the revolutionary moment, played very different roles in the ideas and practices of the French and American revolutions. In France, constituent power was seen to be the source of the law and constitutions; as such, its fluid and unstable nature resulted in constituent assemblies and constituents riven by conflict, resulting in instability throughout the 19th and even 20th centuries. The American experience, on the other hand, did not rely on constituent power to found its legal foundation, at least according to Arendt. Instead, the American founders drew on the idea of covenanting which they derived from the charters and common law traditions of England, which they brought with them to found their order. Arendt argues that this heritage of common law gave the American experience something more worldly and stable upon which to found their constitutional order. ${ }^{36}$ The American constitution, while the result of a meeting of individuals who represented their constituents, was also the result of an engagement with historical traditions of thought and practice that give it more solidity than a revolutionary document designed to capture the general will, as in France. Arendt is not here disputing the importance of a revolution or privileging the Thermidor over the power of the radicalism; rather, she is arguing that there needs to be something concrete and worldly upon which the results of the revolution can rest, a constitution that can guide the republic through its revolutionary period.

After establishing that the distinction between law and power in the American context made it more successful than the French revolution, Arendt turns in the next chapter to themes she had addressed in Between Past and Future and in "Introduction into Politics." We find her discussions of the Roman conception of law, its reliance on the ideas of authority,

\footnotetext{
${ }^{36}$ Arendt, On Revolution, p. 157.
} 
tradition, and religion at their founding. ${ }^{37}$ These foundational elements are read into the American experience, finding in references to the republican tradition by the founders parallels to Roman efforts. The American founders' reliance on the charters of the 17th century and the covenants of the Pilgrims reinforces these foundational elements, drawing on Ancient Israelite traditions rather than simply Roman ones. Their respect for the authority of tradition gives the American experience something that the French, with their desire to sweep away all vestiges of the old order, failed to capture. Yet the American experience should not be confined to the authority of tradition, for Arendt reminds us that it was still a revolution, a break with the established order. It is the dialectic between the history of the tradition and the natality of the act of revolution that is at the core of Arendt's account of the American experience.

I criticized Zaid al Ali for his argument that "progressives" should be the ones who write a constitution for Egypt, suggesting that respect from traditions of thought within Egyptian history might produce a better outcome. Based on Arendt's point noted above, one might argue that the traditionalist arguments of the Muslim Brotherhood might have been better situated to protect those traditions. What needs clarifying is that modern Islamist movements are not "traditional"; rather, they are modern efforts to radically redefine the past to suit their understandings of the present. As Gilles Kepel has argued, these movements only emerged in the mid $20^{\text {th }}$ century, largely in response to crises brought on by decolonization, poverty, and oppressive governments. ${ }^{38}$ Of course, there are many more explanations of political Islam than can be found here, but it captures a sentiment that is important to emphasize. The activism of the Islamic parties in the Egyptian context is not an attempt to

\footnotetext{
${ }^{37}$ See her essay, "What is Authority" pp. 91-142 in Between Past and Future: Eight Exercises in Political Thought (New York: Penguin Publishers, 1961).

${ }^{38}$ See Gilles Kepel, Muslim Extremism in Egypt: The Prophet and the Pharaoh (Berkley CA: University of California Press, 1986) and Jihad: The Trail of Political Islam (Cambridge MA: Harvard University Press, 2002).
} 
return to traditions in the way that Arendt argued the American founders did. Rather, these movements, ironically, embody the spirit of the French and Bolshevik revolutions which sought moral purity in pursuit of representing the people, a sentiment perhaps best embodied in the Iranian revolution of 1979.

One alternative approach is to look to a truly traditional, and very old, institution within Egypt: Al Azhar University. The oldest university in the world, and a bastion of Islamic thought, Al Azhar has long served as a point of pride among Egyptians. During the Nasser era, al Azhar's independence was severely curtailed, giving the government more power to control it. During the 2012-2013 period of power by the Muslim Brotherhood, some of that control was returned to the institution and its role in advising the government was increased. For some, this augured political Islam, but this misunderstands al Azhar's image and role in Egyptian society. It has long argued for a moderate interpretation of Islam, with its webpage stating "Al-Azhar University is looking forward to being the leading university worldwide for presenting the correct Islamic thought based on moderation". ${ }^{39}$ Moreover, if there is such a thing as Islamic constitutionalism, it is defined by giving a role not necessarily to clerics but to scholars. ${ }^{40}$ To give some influence to scholars at al Azhar might perhaps be the type of constitutional innovation that would respect the traditions of the past in the way that Arendt suggests. And, tellingly, the current regime in Egypt sees Al Azhar as a threat. In 2017, the al Sisi regime sought to push through legislation that would take control away from the university and return it to the government. ${ }^{41}$

Of course, this suggestion should not be seen as the solution to the problems of creating greater public freedom in Egypt. Arendt did not argue that religion would solve the

\footnotetext{
39 http://www.azhar.edu.eg/en/.

${ }^{40}$ See Noah Feldman, The Rise and Fall of the Islamic State (Princeton: Princeton University Press, 2008) and Rainer Grote and Tilman J Röder, eds., Constitutionalism in Islamic Countries: Between Upheaval and Continuity (Oxford: Oxford University Press, 2012).

${ }^{41}$ Nathan Brown and Mariam Ghanem, "The Battle Over al Azhar" Carnegie Middle East Center, 31 May 2017, available at: http://carnegie-mec.org/diwan/70103.
} 
problems of politics. And, she would be wary of the ways in which Islamic jurisprudence focuses so directly on personal matters, and frames such guidance in terms of morality. Yet, she did privilege the ways in which the American founders drew from their religious and philosophical heritage to establish the legal order necessary to protect the revolutionary treasure.

The last element of On Revolution that might help us to interpret events in Egypt comes from her idea of the "lost treasure". The American founders sought to create permanence and durability in their institutions, which meant they failed to uphold the centrality of freedom and the force of political natality. While the success of the American experience in contradistinction to the French was its ability to draw on the past in founding its legal and constitutional order, it went too far, according to Arendt's reading. When the founders moved to formalize the revolution in the creation of a constitution, they failed to leave space for the "townships and the town-hall meetings, the original springs of all political activity in the country" ${ }^{42}$ In seeking to create national institutions through a constitutional assembly, the spirit of political action that had motivated the revolution in the first place was lost.

Here Arendt turns back to the French Revolution's critique of representation. While Robespierre criticized representation for failing to capture the will of the people, Arendt argues that representation fails to give people the motivation to act on their own, to engage in political activity on a daily basis. She points to the way in which small groups appear in all revolutions, from the American town hall to the Parisian communes to the Russian soviets. Thomas Jefferson celebrated the councils of early America as a resource that must be treasured, and Arendt sees in his vision the lost treasure of the revolution. It is the ability to continue acting in political life, the centrality of these daily modes of political participation,

\footnotetext{
${ }^{42}$ Arendt, On Revolution, p. 239.
} 
that need to be rescued. Arendt recognizes, of course, as did Jefferson, that to give space to these councils will undermine the larger political order. Jefferson's famous line that the 'tree of liberty must be nourished with the blood of revolution' is then not only about large scale national revolution, but about the continued potential of the people acting together that might challenge the established order. Arendt continues this line of thought by critiquing the creation of a party system in the early American Republic, for parties are oriented toward representation and the creation of professional politicians, while the council system was oriented toward the creation of spaces for citizens to be citizens, to be active members of political life and to prevent an elite or a set of institutions from dominating their political existence. $^{43}$

Does anything like this exist in the Egyptian political system? Perhaps not now, but it is clear that the revolution came about as a result of such efforts. As noted above, Wael Ghonim, a young Egyptian employee of Google, played a crucial role in the protest movements in early February 2011. His appearance on television, pleading with his fellow Egyptians to not give up hope, inspired many to continue when it appeared the government was regaining the initiative. Ghonim was not simply a random young person who turned the tide. His activism was begun through his interactions with Mohammed el Baradei, the Egyptian liberal who had previously served as Director of the International Atomic Energy Agency. El Baradei was seen as a strong contender among liberals for the presidency, and even served for a period as Vice President under President al Sisi. Ghonim was important in using social media to promote El Baradei in 2009 and 2010.

But it was Ghonim's discovery of the death of Khaled Said, a young man from Alexandria, which really spurred his activism. On 8 June 2010, he came across a photo of the young man's destroyed face on Facebook. It was claimed by the Alexandrian police that he

\footnotetext{
${ }^{43}$ Arendt, On Revolution, p. 273.
} 
died of a drug overdose, but the photo of him clearly indicated he had been beaten to death. Ghonim was disturbed and created a Facebook page called Kullena Khaled Said, or We are all Khaled Said. This page soon became an online community of people, which Ghonim then organized into a silent protest in Alexandria and Cairo. This non-violent protest included the mother of Khaled Said, in which participants stood wearing black in silent protest. While not large, Ghonim's ability to create a community on line which then created a community in the streets fed into the revolution.

Ghonim connected this activism with a pre-existing group of online activists who called themselves the April 6 Movement. This name cane from labour protest that had taken place on 6 April 2008 at the Al Mahalla Textile Factory in al Khubra. Ghonim and others used this existing community, one in which forms of participatory activism through Twitter, Facebook, and email exchanges helped bring out the large numbers of individuals who eventually ended up not just in Tahrir Square but more widely throughout the country. He and others continued to use online activism throughout the revolutionary period, helping to encourage and direct protestors to different locations during the protests.

Clearly, this online activism is not the ideal of which Arendt speaks. But, it does suggest that there is something to this form of activism which mirrors the small scale politics of the council and soviet. Importantly, this form of activism has not disappeared under the new restrictions imposed by the al Sisi regime, though they have done their best to quash it. ${ }^{44}$ The very act of creating these online links, however, and establishing a name and platform for such activism is, in some sense, close to what Arendt suggested in her concluding chapter of On Revolution. In Egypt today, to attempt protest or even meeting in physical form is dangerous. Yet, the efforts of online activists to continue is heartening and represents a form

\footnotetext{
${ }^{44}$ Joshua Hammer, "How Egypt's Activists became Generation Jail” New York Times, 14 March 2017, available online at: https://www.nytimes.com/2017/03/14/magazine/how-egypts-activists-became-generation-jail.html.
} 
of political activism which might be a way to achieve the public freedom to which revolutions should be directed.

\section{Conclusion}

This chapter has tried to use Arendt's On Revolution to think through the dynamics of the Egyptian revolutions of the past 7 years. As noted in the Introduction, the future does not look bright. I have suggested that perhaps some of the reasons for the collapse of that failure arises from the same problems that Arendt saw bedevilled the French Revolution; a focus on a progressive revolutionary spirit as opposed to taking seriously existing traditions which might help to undergird the revolution; the moralism of finding an enemy in order to assert the reality of constituent power; and a belief that simply writing a constitution that lists rights rather than one that ensures political institutions that reflect power dynamics will solve a country's problems.

These problems are not unique to Egypt nor can they be blamed on the Egyptian liberals or progressives. If Arendt is right, we may have lost a shared revolutionary treasure, one that would allow us to continue renewing political institutions without falling into a Thermidorian trap. I suggested that the online activism that brought about Tahrir Square might be one small sign of hope that even in a country where the revolutionary spirit seems to have disappeared completely.

Arendt also gives us one other sign of hope. In an interview conducted some years after the publication of On Revolution, Arendt suggests that the future of revolutionary movements might be found in a global space rather than a national one:

I see the possibility of forming a new concept of the state. A council state of this sort, to which the principle of sovereignty would be wholly alien, would be admirably suited to federations of the most various kinds, especially because in it power would be constituted horizontally and not vertically. But if you ask me now what prospects it has of being realized, 
then I must say to you: Very slight, if at all. And yet, perhaps, after all - in the wake of the next revolution. ${ }^{45}$

The fact that Egypt's revolution was part of a wider Arab dynamic, and perhaps even a wider global dynamic, suggests that there be something to Arendt's hint. Perhaps it is not through recasting the Egyptian constitution that public freedom will be found, but through the creation of non-sovereign, pluralist global constitutional orders that the future of the revolutionary tradition lies. For the sake of those Egyptians who fought and died in the last few years, we can only hope that their continued presence in online councils will help to connect them with others around the world in pursuit of political action and public freedom.

\section{Bibliography}

Abat I Ninet, Antoni and Mark Tushnet. The Arab Spring: An Essay on Revolution and Constitutionalism. Cheltenham: Edward Elgar Publishers, 2015.

ABC News. http://abcnews.go.com/International/wireStory/egypt-detains-pro-governmenttv-host-police-segment-53498339. Accessed 1 April 2018

Al Ahram. "Official: The 100 Members of Egypt's Revamped Constituent Assembly." Ahram Online, 12 June 2012. http://english.ahram.org.eg/NewsContent/1/64/44696/Egypt/Politics-/Official-The-members-of-Egypts-revamped-Constitue.aspx.

Al Ahram. "Who's Who: Members of Egypt's 50-member Constitution Committee." Ahram Online, 1 Sep 2013. http://english.ahram.org.eg/News/80519.aspx.

\footnotetext{
${ }^{45}$ Hannah Arendt, Crises of the Republic (New York: Harcourt Brace Jovanovich, 1972), p. 233.
} 
al Ali, Zaid. “Egypt's Third Constitution in Three Years: A Critical Analysis.” In Egypt's Revolutions: Politics, Religion and Social Movements, edited by Bernard Rougler and Stéphane Lacroix, 123 -138. London: Palgrave Macmillan, 2016.

al Aswany, Alaa. Democracy is the Answer: Egypt's Years of Revolution, translated by Russel Harris, Aran Byrne, and Paul Naylor. London: Gingko Library, 2014.

Al-Azhar University. http://www.azhar.edu.eg/en/. Accessed 15 April 2018

al Chazli, Fattouh. "Egypt's Constitutional Drafting: A Comparative Review.” The Legal Agenda, 31 December 2013. http://www.legal-agenda.com/en/article.php?id=2958.

Arendt, Hannah. The Human Condition. Chicago: University of Chicago Press, 1958.

Arendt, Hannah. Between Past and Future: Eight Exercises in Political Thought. New York: Penguin, 1961.

Arendt, Hannah. On Revolution. (New York: Penguin Books, 1963)

Arendt, Hannah. Crises of the Republic. New York: Harcourt Brace Jovanovich, 1972.

Bernard-Muagiron, Nathalie, ed. Judges and Political Reform in Egypt. Cairo: The American University in Cairo Press, 2008.

Brown, Nathan. "Egypt's Constitutional Ghosts." Foreign Affairs (February 2011), reprinted at Carnegie Endowment for International Peace.

http://carnegieendowment.org/2011/02/15/egypt-s-constitutional-ghosts/930.

Brown, Nathan and Mariam Ghanem. "The Battle Over al Azhar.” Carnegie Middle East Center, 31 May 2017. http://carnegie-mec.org/diwan/70103.

Cook, Steve. The Struggle for Egypt: From Nasser to Tahrir Square. Oxford: Oxford University Press, 2012.

El-Bhsiry, Tarek. “Egypt’s New Legitimacy.” The Guardian, 21 March 2011. http://www.guardian.co.uk/commentisfree/2011/mar/21/egypt-referendum-constitutionlegitimacy-change. 
El-Din, Gamal Essam. “A Stilborn Assembly.” Al Ahram Weekly, 5-11 April 2012. http://weekly.ahram.org.eg/2012/1092/eg1.htm.

Feldman, Noah. The Rise and Fall of the Islamic State. Princeton: Princeton University Press, 2008 .

Grote, Rainer and Tilman J. Röder, eds. Constitutionalism in Islamic Countries: Between Upheaval and Continuity. Oxford: Oxford University Press, 2012.

Hammer, Joshua. “How Egypt's Activists became Generation Jail.” New York Times, 14 March 2017. https://www.nytimes.com/2017/03/14/magazine/how-egypts-activistsbecame-generation-jail.html.

Hanssen, Jens. "Translating Revolution: Hannah Arendt in Arab Political Culture.” HannahArendt.net, http://www.hannaharendt.net/index.php/han/article/view/301.

Human Rights Watch. "We Do Unreasonable Things Here: Torture and National Security in al-Sisi’s Egypt.” Human Rights Watch Report, 5 September 2017. https://www.hrw.org/report/2017/09/05/we-do-unreasonable-things-here/torture-andnational-security-al-sisis-egypt.

Kepel, Gilles. Muslim Extremism in Egypt: The Prophet and the Pharaoh. Berkley, CA: University of California Press, 1986.

Kepel, Gilles. Jihad: The Trail of Political Islam. Cambridge, MA: Harvard University Press, 2002.

Khalil, Ashfar. "Egypt's Committee of 50 Rewrites the Constitution - Again." Al Jazeera America, 11 November 2013. http://america.aljazeera.com/articles/2013/11/11/egyptconstitutioncommitteeof50.html.

Lang, Anthony F., Jr. “Arendt and the Question of Revolution.” In Hannah Arendt: Key Concepts, edited by Patrick Hayden, 167-184. London: Routledge, 2014. 
Lang, Anthony F., Jr. "From Revolutions to Constitutions: The Case of Egypt.” International Affairs 89, no. 2 (2013): 345-364.

Lang, Anthony F., Jr. "Violence and International Political Theory." In The Oxford Handbook of International Political Theory, edited by Chris Brown and Robyn Eckersley, 195-208. Oxford: Oxford University Press, 2018.

Loughlin, Martin. "The Concept of Constituent Power." European Journal of Political Theory 13, no. 2 (2014): 218-237.

Loughlin, Martin and Neil Walker, eds. The Paradox of Constitutionalism: Constituent Power and Constitutional Form. Oxford: Oxford University Press, 2007.

Rougler, Bernard and Stéphane Lacroix, eds., Egypt's Revolutions: Politics, Religion and Social Movements, translated by Cynthia Schoch with the participation of John Angell. London: Palgrave Macmillan, 2016.

Shehata, Said. "Profile: Egypt's Freedom and Justice Party." BBC News, 25 November 2011. http://www.bbc.co.uk/news/world-middle-east-15899548.

Walsh, Declan. “As Election Nears, Egypt Finds a New Target: Foreign News Media.” The New York Times, 28 February 2018. https://www.nytimes.com/2018/02/28/world/middleeast/egypt-elections-newsmedia.html.

Walsh, Philip. “On the Social.” In Hannah Arendt: Key Concepts, edited by Patrick Hayden, 124-137. London: Routledge, 2014. 